\title{
REVIEW
}

\section{LICHENS: A CHEMICALLY IMPORTANT BIOTA}

\author{
VERANJA KARUNARATNE*, KARUNANANDA BOMBUWELA, SELVALUXMY \\ KATHIRGAMANATHAR and VINITHA M. THADHANI
}

Department of Chemistry, University of Peradeniya, Peradeniya.

(Accepted: 03 October 2005)

\begin{abstract}
Lichens produce a wide variety of secondary metabolites which assist them in the colonization of terrestrial habitats. Such compounds are important in the chemotaxonomy of lichens. Furthermore, lichen substances exhibit antiherbivore, antimicrobial and antineoplastic activities. This review highlights the different types of lichen substances and their activities, uses and the possible ecological role.
\end{abstract}

Lichens are symbiotic organisms of fungi (mycobiont) and algae (photobiont) comprising about 17,000 species. Lichens are unique because they look and behave quite differently from their component organisms. They are classified and named according to their fungal partner, with many thousands of species of lichens sharing a much smaller number of photobiont species. Lichens show a world-wide distribution commonly growing on rocks and poorly developed soils such as those of arid lands and boreal-arctic regions or as epiphytes on trees and shrubs.

Primary metabolites of lichens, which are intracellular, are proteins, amino acids, polyols, carotenoids, polysaccharides and vitamins. Lichens produce a wide array of secondary metabolites (extracellular). There are over 700 lichen substances reported to date ${ }^{1}$ and many are restricted to the lichenised state. Broadly speaking, there are three major types of lichen substances based on their biosynthetic pathways. ${ }^{2}$

(a) Depsides, depsidones and dibenzofurans formed by the acetate-malonate pathway. The most important of these are the esters and the oxidative coupling products of simple phenolic units related to orcinol and $\beta$-orcinol. Most depsides and depsidones are colourless compounds which occur in the medulla of the lichen. However, usnic acids, yellow cortical compounds formed by the oxidative coupling of methylphloroacetophenone units are found in the cortex of many lichen species (Figure 1). Anthraquinones, xanthones and chromones, are all pigmented compounds which occur in the cortex, which are also produced by the acetate-malonate pathway by intramolecular condensation of long folded polyketide units rather than the coupling of phenolic units (Figure 2).

(b) The shikimic acid biosynthetic pathway produces two major groups of pigmented compounds, which occur in the cortex: pulvinic acid derivatives and terphenyl quinones (Figure 3). Although most pulvinic acid derivatives lack nitrogen, they are biosynthesized through phenyl alanine. Nitrogen is strongly limiting to metabolic activities in most lichens, and nitrogen rich metabolites such as alkaloids are unknown among lichen substances.

(c) Terpenes and steroids are produced by the mevalonic acid pathway. These include compounds unique to lichens and many that occur in higher plants as well (Figure 4).

\section{Chemotaxonomy of lichens}

The application of chemical discriminators to lichen taxonomy is widely accepted. The secondary metabolites in about 5000 species (33\% of all known species) have been studied and the data are used in the routine identification of lichens than in any other group of organisms. ${ }^{3,4}$

Cortical chemistry: It has now been recognized by many lichenologists that some cortical substances

\footnotetext{
* Corresponding author
} 
<smiles>Cc1cc(OC(=O)c2c(C)cc(O)cc2O)cc(O)c1C(=O)O</smiles>

Lecanoric acid (para-Depside)<smiles>Cc1cc(COOC(=O)c2c(C)cc(O)cc2O)cc(O)c1C(=O)O</smiles>

Alectorialic acid (Benzyl depside)<smiles>Cc1cc(OC(=O)c2c(C)cc(OC(=O)c3c(C)cc(O)cc3O)cc2O)cc(O)c1C(=O)O</smiles>

Gyrophoric acid

(Tri depside)<smiles>CCc1cc(Oc2cc(OC)cc(CC)c2C(=O)O)cc(O)c1C(=O)O</smiles>

Micareic acid (Diphenyl ether)

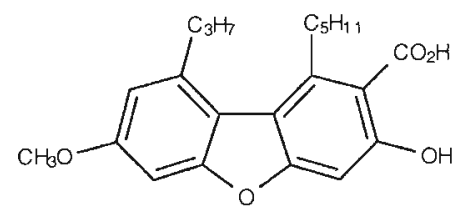

Didymic acid

(Dibenzofuran)<smiles>CCCCCc1cc(O)c(OC(=O)c2c(C)cc(OC)cc2O)c(O)c1C(=O)O</smiles>

Sekikaic acid (meta-Depside)<smiles>CC(=O)C1=C(O)C=C2Oc3c(C(C)=O)c(O)c(C)c(O)c3C2(C)C1=O</smiles>

Usnic acid<smiles>Cc1cc(O)c(C=O)c2c1C(=O)Oc1c(C)c(O)c(C(=O)O)c(C)c1O2</smiles>

Virensic acid (Depsidone)<smiles>CC1=CC(=O)C=C(C)C12C(=O)Oc1cc(O)c(C(=O)O)c(C)c12</smiles>

Picrolichenic acid

(Depsone)

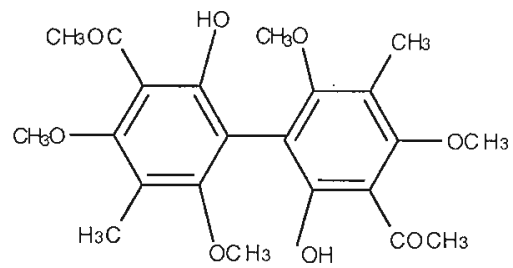

Contortin (Biphenyl)

Figure 1: Structures of typical acetyl-polymalonyl lichen products derived from two or more polyketide chains. 
Aliphatic acids

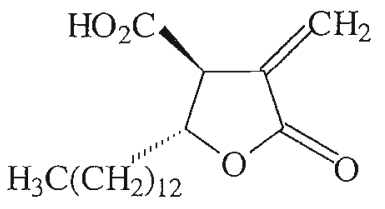

(+)-Protolichesterinic acid

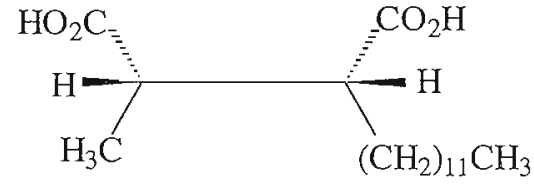

Roccellic acid

\section{Mononuclear phenolic compounds}<smiles>Cc1cc(O)cc(O)c1C(=O)O</smiles>

Orsellinic acid

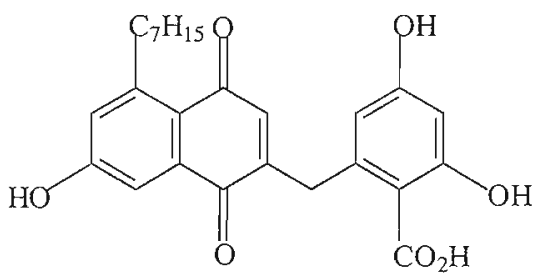

Siphulin (Chromone)<smiles>COC1=CC(=O)c2c(O)c3c(c(O)c2C1=O)CC(C)OC3=O</smiles>

Haemoventosin (Naphthaquinone)<smiles>Cc1cc(O)c(C)c(O)c1C(=O)O</smiles>

$\beta$-Orsellinic acid<smiles>COc1cc(C)c2c(=O)c3c(O)cc(OC)cc3oc2c1</smiles>

Lichexanthone (Xanthone)

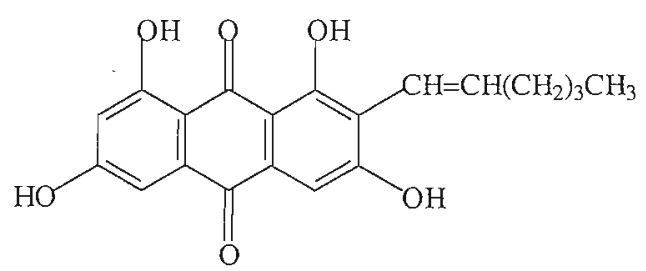

Averythrin (Anthraquinone)

Figure 2: Structures of some acetyl-polymalonyl lichen products derived from a single polyketide chain. 


\section{Pulvinic acid derivatives}<smiles>O=C1O/C(=C(/C(=O)O)c2ccccc2)C(O)=C1c1ccccc1</smiles>

Pulvinic acid<smiles>O=C1O/C(=C2\C(=O)Oc3ccccc32)C(O)=C1c1ccccc1</smiles>

Calycin

\section{Terphenyl quinones}<smiles>O=C1C(O)=C(c2ccccc2)C(=O)C(O)=C1c1ccccc1</smiles>

Polyporic acid<smiles>O=C(O)Cc1c[nH]c2ccccc12</smiles>

Indolyl-3-acetic acid<smiles>O=C1c2oc3cc(O)c(O)cc3c2C(=O)C2c3cc(O)c(O)cc3OC12</smiles>

Thelephoric acid

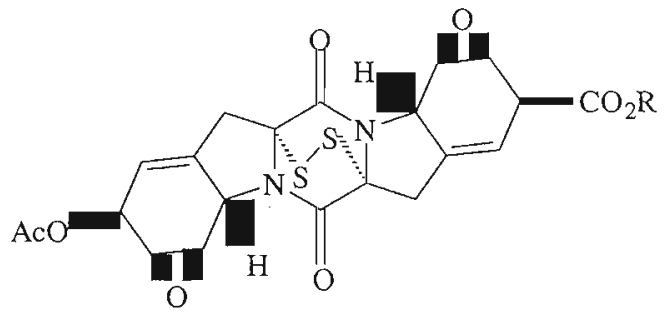

Ambewelamide A, $1 \mathrm{R}=\left(\mathrm{CH}_{2}\right)_{2} \mathrm{CH}_{3}$ Ambewelamide $\mathbf{B}, 2 \mathrm{R}=\left(\mathrm{CH}_{2}\right)_{4} \mathrm{CH}_{3}$

Figure 3: Structures of some lichen products derived from the shikimic acid pathway.

\section{Terpenoids}<smiles>CC1C(=O)C2(C(C)C)CCC1C2</smiles>

(-)- $\beta$-Thujone (Monoterpenoid)<smiles>[M][C@]12CCC3C[C@](C)(C=C)CCC3C1(C)CCC[C@@H]2C(=O)O</smiles>

(-)-Sandaracopimaric acid (Diterpenoid)<smiles>C=C1COC(=O)[C@]12CC1(C)C(C)CCC[C@]1(C)C2</smiles>

Fukinanolide (Sesquiterpenoid)

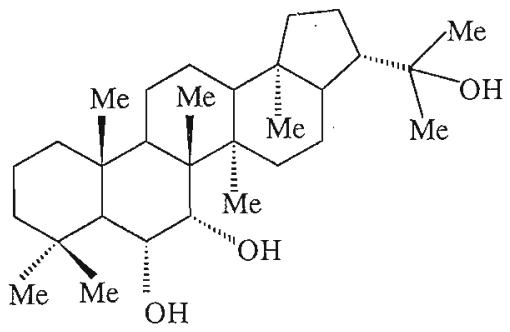

Hopan-6 $\alpha, 7 \alpha, 22$-triol (Triterpenoid) 
<smiles>[Y4]C(C)C(C)C=CC(C)C(C)C</smiles>

Ergosterol (Steroid)<smiles>[M]C1(C)CCCC(C)C1C=CC(C)=CC=CC(C)=CC=CC=C(C)C=CC=C(C)C=CC=C(C)C=CC=C(C)C</smiles>

Figure 4: Structures of typical lichen products derived from the mevalonic acid pathway.

are correlated with higher taxonomic ranks. For example, vulpinic acid in Letharia (at the genus level) or anthraquinones such as parietin in Teloschistaceae (at the family level). ${ }^{5}$

\section{Medullary chemistry}

Variations in medullary constituents are used mainly as discriminators at the species level. Most morphologically defined species have a constant chemistry, regardless of their geographical location, substrate or ecology. Within a complex of morphologically similar species, three common patterns of chemical variation can be discerned: (a) replacement compounds, (b) chemosyndromic variation and (c) accessory type compounds. ${ }^{4}$

With replacement compounds, cogeneric chemotypes show simple replacement of one substance by another. Morphologically these lichen populations are sometimes indistinguishable, but possess well-defined and constant variations in chemical compositions. For example, Psuedovernia furfuraceae has three chemical races. One race contains olivetoric acid and is found in Northern Europe, a second is found in Southern Europe and Northern Africa and contains physodic acid and third containing lecanoric acid is found in North America. Biogenetically the first two compounds are closely related because one can be derived from the other by one single step. But lecanoric acid is not biosynthetically related to these two compounds. It is therefore now recognized that when biogenetic demarcations complement biogeographic variations, such taxa should be recognized as separate species. Thus, the North American taxon is named as $P$. consocians. ${ }^{2}$ However, it has been suggested that the best way to recognize whether chemical variation is under genetic control or not is through sympatric chemical races which maintain their chemical integrity even when growing side by side. ${ }^{3}$

Chemosyndrome refers to a group of biosynthetically related lichen substances and the major metabolite is accompanied by several minor constituents which are biosynthetically related. ${ }^{4}$ The compounds which are major constituents in one species may occur as minor constituents in related taxa and vice versa. These chemotypes can also be considered as sibling species ${ }^{5}$, where reproductive isolation of a species often leads to ecological differentiation. This is a common result of evolution in animals and vascular plants.

The occurrence of accessory compounds may tend to complicate the above arguments. These compounds are found at certain times in species, usually in addition to normal constituents, and have relation to the morphological or distributional variation. Thus, these compounds are not accorded chemotaxonomic significance. Such compounds 
often occur as accessory compounds in more than one species and often vary in quantity.

The following spot tests and microchemical methods will be used to garner taxonomical details of lichen specimens:

\section{(a) Chemical (colour) tests conducted on lichen thalli}

The common spot test reagents not only indicate where particular compounds are located in sectioned thalli, but may also indicate the chemical nature of the substance.

Reagents for thalline spot tests:

$\mathrm{K}=10 \%$ aqueous $\mathrm{KOH}$ solution

a. Turns yellow to red with most $o$-hydroxy aromatic aldehydes

b. Turns bright red to deep purple with anthraquinone pigments

$\mathrm{C}=$ saturated aqueous $\mathrm{Ca}(\mathrm{OCl})_{2}$ or common bleach $\mathrm{NaOCl}$ solution

a. Turns red with $m$-dihydroxy phenols, except for those substituted between the hydroxy groups with a $-\mathrm{CHO}$ or $-\mathrm{CO}_{2} \mathrm{H}$.

b. Turns green with dihydroxy dibenzofurans.

$\mathrm{KC}=10 \%$ aqueous $\mathrm{KOH}$ solution followed by saturated aqueous $\mathrm{Ca}(\mathrm{OCl})_{2}$ or common

bleach $(\mathrm{NaOCl})$ solution.

a. Turns yellow with usnic acid.

b. Turns blue with dihydroxy dibenzofurans.

c. Turns red with depsides and depsidones which, undergo rapid hydrolysis to yield $m$ dihydroxy phenolic moiety.

$\mathrm{PD}=5 \%$ alcoholic $p$-phenylenediamine solution

a. Turns yellow, orange or red with aromatic aldehydes.

\section{(b) Microchemical methods}

(i) Standardized TLC methodology: Commercial silica gel plates and three solvent systems (designated A, B \& C) and two internal controls (atranorin and norstictic acid) are used. ${ }^{6,7,8} \mathrm{All} \mathrm{R}_{\mathrm{f}}$ values are compared. An acetone extract of the lichen is spotted on the plate and subsequently eluted in each solvent system. For each solvent system, a spot is assigned to a $R_{\mathrm{f}}$ class determined by the position relative to the standards. Data are then sorted to find all compounds with the same $R_{f}$ classes. Of these possibilities, those with similar spot characteristics (colour, fluorescence etc.,) are compared chromatographically with the unknown. Additional solvent systems are used for compounds that do not separate well in the initial analysis. Two-dimensional TLC methods are used to evaluate structurally similar compounds. Before spraying the dried plates are examined in day light for pigments and for fluorescence or quenching under short $(254 \mathrm{~nm})$ and long wavelength (365 $\mathrm{nm}$ ) ultraviolet (UV) light. Subsequently the plates are sprayed with $10 \%$ sulfuric acid and heated at $110^{\circ} \mathrm{C}$ on a hot plate for 10 minutes to develop the spots. The following solvent systems are used:

Solvent A = Toluene: dioxane: acetic acid (180: 45:5)

Solvent B = Hexane: methyl tert . butyl ether: formic acid (140: 72: 18)

Solvent C = Toluene: acetic acid (170: 30)

Additional solvents:

Solvent E = Cyclohexane: ethyl acetate (75: 25)

Solvent G = Toluene: ethyl acetate: formic acid (139: 83: 8)

(ii) High performance liquid chromatography (HPLC): Samples are dissolved in methanol and eluted through the appropriate partition column by using a suitable solvent or solvent system under high pressure. The substances that separate are detected in a UV detector. The retention time $R_{t}$ and peak intensity are recorded by a chart recorder. HPLC is also used to measure either absolute or relative concentrations of lichen compounds. Gradient elution methods are used. The RI value of an unknown peak is calculated as follows:

$R I=\frac{R_{t} \text { of Peak }-R_{t} \text { of benzoic acid } \times 100}{R_{t} \text { of Solorinic acid }}$

RI values are very stable during the lifetime of a column. Substances which are eluted at the same time often belong to different substance classes and can be distinguished by their UV spectra. 
(iii) Gas Chromatography and Mass Spectrometry: Xanthones, anthraquinones, dibenzofurans, terpenes and pulvinic acid which lack thermolabile ester groups can be studied by gas chromatography coupled with mass spectrometry (GCMS). Xanthones in lichens were studied by injecting a lichen extract directly into a mass spectrometer. ${ }^{9}$ More recently, the main terpenoid components of the lichens of the family Pyxinaceae have been studied by GCMS. ${ }^{10}$

\section{Ecological role of lichen substances}

A significant number of lichen substances are not present in non-lichenised fungi. Many genera of lichens also do not produce any of the characterized products. Thus the presence of these compounds are not required to maintain the symbiotic state.

Lichen substances are found deposited in either the cortex or the medulla as crystals or on the outer surface of hyphae. The commonest cortical compounds are usnic acid and atranorin. Anthraquinones, pulvinic acid derivatives and xanthones also occur in the cortex to a lesser degree. All these compounds with the exception of atranorin are pigmented. The majority of lichen substances are deposited in the medulla. Concentrations of lichen substances are variable and typically it is around $1 \%$ but values of 5-6\% are not uncommon. Once formed, lichen substances are very stable. In lichens, there is no correlation between growth rates and concentration of lichen substances, although high concentrations are found at actively growing lobe or branch tips as well as soralia and apothecial margins. There appear to be several roles of lichen substances which determine the relative ecological success of individual lichen species and the structure and diversity of natural lichen communities: (a) light-screening compounds, (b) chemical withering compounds, (c) biologically active compounds, (d) anti-herbivore defense compounds and (e) Allergenic compounds: ${ }^{1}$

\section{(a) Light-screening compounds}

Many cortical lichen substances show variation in concentration along light gradients. Evidence suggests that these compounds act as lightscreens, regulating the light intensity reaching the algal layer in the upper cortex. Usnic acid, a yellow cortical pigment is the most widespread lichen substance found in thousands of lichens. Lichen populations having usnic acid which are exposed to the sun are yellow, while the shade populations are grey-green, indicating a lower concentration of the depside. Cladonia subtenuis and Parmeliopsis ambigua show concentrations of usnic acid varying along concentration gradients. ${ }^{11}$

Anthraquinones such as parietin (a reddish cortical pigment) appear to act like usnic acid acting as a light filter. This compound is characteristic of species within Teloschistaceae. These species occur in exposed habitats. In extreme desert environments, species of Caloplaca may be the only saxicolous lichens present, while Xanthoria and Caloplaca dominate highly exposed coastal areas. Pigmented xanthones in the outer cortex of many crustose lichens may also play a role in regulating the light intensity reaching the algal layer. These xanthones which are yellow or brown in colour occur in many species of Lecanora, Pertusaria, Melanaria, Lecidea and Buellia in habitats with high light intensities. Unlike fungal xanthones, lichen xanthones contain one or more chlorinated substituents, suggesting that the availability of chloride in the environment may affect the production of these compounds. ${ }^{3}$

\section{(b) Chemical withering compounds}

Lichen substances such as phenolic compounds with carbonyl functional groups play an important role in the withering of rock due to their ability to complex metal ions. ${ }^{12}$ This process leads to soil formation. Low but significant amounts of these substances dissolve in water. Solubility is determined by the nature and the number of polar groups present. The metal complexation is advantageous to many crustose and foliose lichens growing in close proximity to rock substrate: Since lichen substances commonly occur as crystals on the outer surfaces of hyphae, it puts them in direct contact with the substrate where biochemical withering could aid attachment. 


\section{(c) Biologically active compounds}

The biological activity of lichen compounds very likely gives them an ecological advantage in colonization of terrestrial areas. Such compounds have been used by man as well. Lichens have been used in medicine by the ancient Chinese and Egyptians. ${ }^{13,14}$ The medicinal use of lichens is not prevalent at present, particularly since the testing of the atom bomb and the Chernobyl accident in 1986 which have increased the concentrations of radionuclides $\left({ }^{137} \mathrm{Cs}\right.$ and ${ }^{40} \mathrm{~K}$ ) to alarming proportions. ${ }^{15}$ According to recent investigations, lichens possess a variety of biological activities:

(i) Antimicrobial activity: Although lichen substances are used as antibiotics, their activity is found to be low compared to those isolated from microorganisms. Furthermore, lichen antibiotics are not adequately water soluble for therapeutic use. Depsides, depsidones and usnic acid are active against Gram-positive microorganisms. ${ }^{16}$ Sodium salt of usnic acid was used as a drug in Russia. ${ }^{17}$ Antiseptic creams such as "Usno" and "Evosin" contain usnic acid. Usnic acid acts by uncoupling phosphorylation and is effective because animal cells are far less permeable to usnic acid than the microorganisms.

In Sri. Lanka, lichens had remained completely unexplored (both chemically and taxonomically) until 1996, when a systematic study to harness their biological and medicinal value was initiated at the Department of Chemistry, University of Peradeniya.

Roccella montagnei is a fruticose lichen, which is pendulous or shrubby. It is sparsely to moderately branched and has shades of grey, specially lilac grey. (Figure 5). ${ }^{1}$ Different Roccella lichen species are used to prepare complex mixtures of pigments for the preparation of litmus paper ( $\mathrm{pH} 4.5$ red; $\mathrm{pH} 8.3$ blue). Two compounds namely, erythrin and methylorsellinate have been isolated from the dichloromethane extract of Roccella montagnei collected from Bamunakotuwa in Kurunegala district.

In general, erythrin showed lower antifungal activity when compared with benomyl (Benlate- standard fungicide) in the TLC bioassay technique. Apart from somewhat reasonable activity shown against Colletotrichum gleosporioides, erythrin exhibited moderate activity against four fungi namely, Colletotrichum musae, Cladosporium cladosporioides, Curvularia trifolii, and Monacrosporium ambrosium. These results were corroborated by a spore germination assay against Colletotrichum musae. The germination was $70.1 \%$ with erythrin at $10 \mathrm{ppm}$, while for the untreated control germination was $74.2 \%$.

Methylorsellinate on the other hand, showed significantly higher antifungal activity as compared to erythrin (Table 1). Methylorsellenate, when tested against Colletotrichum gleosporioides, Colletotrichum musae, Cladosporium cladosporioides and Curvularia trifolii, showed greater activity than the commercial fungicide Benlate. Methylorsellinate showed lesser activity against the fungus, Monacrosporium ambrosium as compared to Benlate. Based on the diameter of inhibition zones, methylorsellinate was significantly more active than erythrin against $C$. cladosporioides.

The antifungal activity of methylorsellinate was also confirmed by a spore germination assay using Colletotrichum musae. The germination percentage with methylorsellinate was $29.9 \%$ while in the control it was $74 \%$.

In order to show that methylorsellinate was not produced as an artifact in the methanol<smiles>Cc1cc(OC(=O)c2c(C)cc(O)cc2O)cc(O)c1C(=O)OCC(O)C(O)CO</smiles>

Erythrin<smiles>CC(=O)c1c(C)cc(O)cc1O</smiles>

Methylorsellenate 


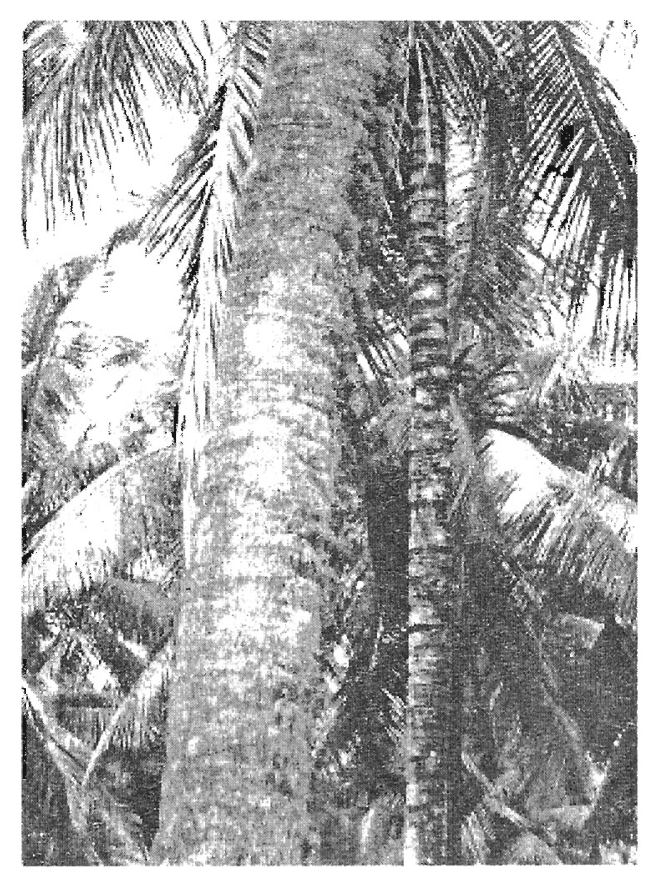

Figure 5: Roccella montagnei lichen growing on the trunk of a coconut tree, Cocos nucifera

Table 1: Antifungal activity of erythrin and methylorsellinate

\begin{tabular}{lccc}
\hline Fungus & \multicolumn{2}{c}{ Inhibition zone diameter/mm } \\
& Erythrin(41) & Methylorsellinate(42) & Benlate \\
\hline Colletotrichum musae & 25 & 50 & - \\
Colletotrichum gloeosporioides & 20 & 44 & 25 \\
Cladosporium cladosporioides & 10 & 50 & 31 \\
Curvularia trifolii & 16 & 55 & 25 \\
Monacrosporium ambrosium & 10 & 36 & 48 \\
\hline
\end{tabular}

extract by the methanolysis of erythrin, the lichen Roccella montagnei was extracted into ethyl acetate. Upon examination by TLC and co-TLC it was evident that this extract also contained both erythrin and methylorsellinate, proving that the latter was indeed a natural product isolated from Roccella montagnei and not an artifact.

Both erythrin and methylorsellinate are almost identical in functionality and in general, phenolic compounds are known to exhibit antifungal properties. In fact the total hydrolysis of erythrin would yield two molecules of orsellinic acid and such the latter could be considered as the biosynthetic precursor of the former. Erythrin is found in large amounts in the lichen $(4.9 \%$ of dry weight) compared with methylorsellinate $(0.3$ $\%$ of dry weight). It is not uncommon that lichen substances are accumulated in amounts exceeding $20 \%$ of the dry weight of the thallus. These compounds are considered to impart a protective role against invading pathogens and herbivores. ${ }^{18}$

Interestingly, in Roccella montagnei the storage of hydrolytically labile erythrin in large amounts (with its relatively low antifungal activity) leads us to reason that the lichen may be converting erythrin to the strongly antifungal methylorsellinate when required. 


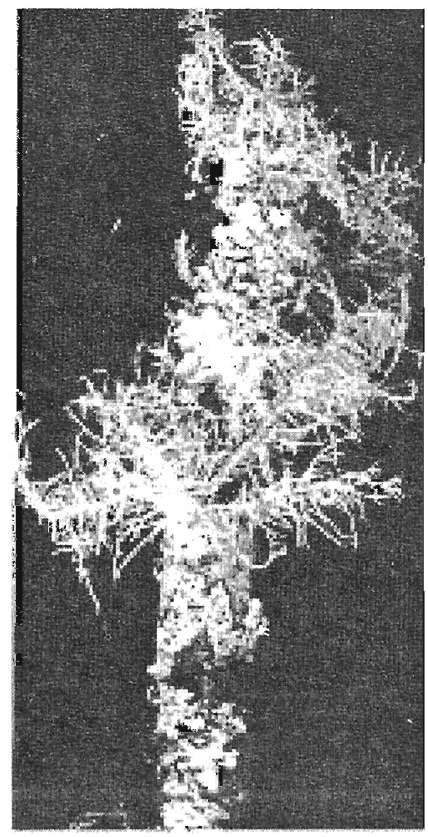

Figure 6: Usnea species from Ambewela growing on decaying Acacia decurrens

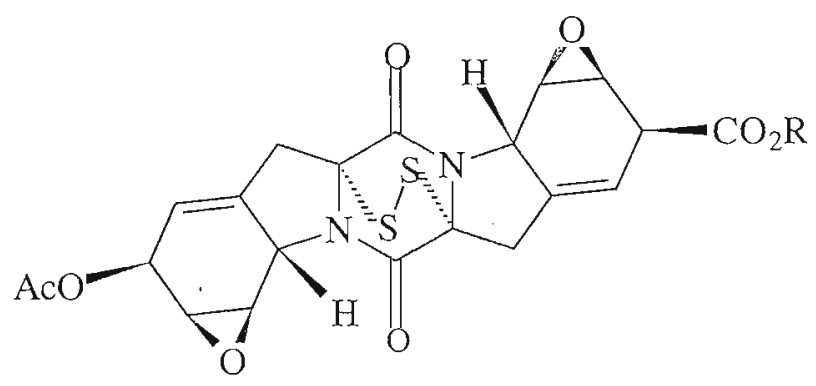

Ambewelamide $\mathbf{A}, \mathrm{R}=\left(\mathrm{CH}_{2}\right)_{2} \mathrm{CH}_{3}$ Ambewelamide $\mathrm{B}, \mathrm{R}=\left(\mathrm{CH}_{2}\right)_{4} \mathrm{CH}_{3}$

(ii) Anti tumour and anti mutagenic activity: (-)Usnic acid ${ }^{19}$, protolichesterinic and nephrosteranic acids ${ }^{20}$, physodalic acid ${ }^{20,21}$, lichen glucans $\mathrm{s}^{22}$ and lichenin derivatives ${ }^{23}$ have shown anti tumour and anti mutagenic activity. Lichen polysaccharides, the class of compounds to which the latter two belong are particularly interesting due to their anti tumour activity. The mechanism of action of these lichen polysaccharides are not completely known, but appears to be host mediated: such compounds are believed to generate lymphoid cells, plasma cells, macrophages in the vicinity of the grafted tumour. ${ }^{24}$

It was found that extracts of the lichen Usnea sp., collected from Ambewela, exhibited potent in vitro cytotoxicity (Figure 6). Bioassay guided fractionation of the Usnea sp. extracts led to the isolation of ambewelamides $\mathrm{A}(\mathbf{1})$ and $\mathrm{B}(\mathbf{2})$, whose structures have been elucidated via a combination of single crystal X-ray diffraction and spectroscopic analyses..$^{25,26}$

Ambewelamides A (1) and B (2) are new members of a family of highly modified diketopiperazines that include fungal metabolites such as aranotin ${ }^{27}$, apoaranotin ${ }^{27}$, emethallicins ${ }^{28}$, exserohilone ${ }^{29}$ and SCH $64847 . .^{30}$ There are reports of anti allergenic ${ }^{28}$, anti viral ${ }^{27}$, EGF receptor binding ${ }^{30}$, phytotoxic ${ }^{29}$ activity for the members of the family of diketopiperazines, but the ambewelamides are the first to show potent cytotoxicity. Ambewelamides are the only members of the family having ring $\mathrm{A} /$ 
E epoxides and a diketopiperazine epidisulphide bridge, suggesting that these functionalities might be necessary for cytotoxicity. The ambewelamides are the first examples of the diketopyperazine family isolated from a lichen.

\section{(d) Anti-herbivore compounds}

Both vertebrate and invertebrate herbivores consume lichens. The reasons for the low observed levels of herbivory may be due to low nutrient content of lichens, the difficulties in metabolising lichens, and the sparse nature of lichens as a resource. Lichens comprise a major source of winter food supply of caribou and reindeer in boreal areas in the Northern Hemisphere. Although lichens are a poor source of proteins (2$3 \%$ ), they are an easily accessible carbohydrate source when higher plant foliage is not available. ${ }^{31}$ In addition, herbivory on lichens by insects, mites, molluscs are important. ${ }^{32,33,34}$ Despite the lichens being a potential food source for herbivores, feeding on lichens is not common. In temperate evergreen forests, there is little evidence of vertebrate or invertebrate herbivory. The resistance of individual lichens to herbivory may be due to a variety of factors. Lichens with gelatinous sheaths covering their surface are relatively immune to herbivory ${ }^{35}$ as seen in some species of Collemataceae. Thick cortical structure with heavily agglutinated hyphae may also provide some protection from small invertebrate herbivores. Inorganic chelate agents present in many saxicolous crustose lichens are toxic to numerous insects. ${ }^{36}$ Four groups of lichen substances that have possible defensive functions in lichens are pulvinic acid derivatives, terpenes, depsides and depsidones and anthraquinones.

Several studies support the primary defensive role of pulvinic acid derivatives. Lichens containing these compounds have relatively high nitrogen content thus making them potentially a valuable food source. Yet, feeding on these taxa are virtually unknown. Vulpinic acid, the most widespread of these compounds is toxic to both vertebrates and invertebrates. ${ }^{37}$ The cortical presence of most of the pulvinic acid derivatives is unusual since they show no variation along light gradients. But this histological position is consistent with their defensive role against herbivores. Since these compounds are bright yellow in colour, their cortical position indicates an example of warning coloration. The medullary position of pulvinic acid derivatives in the Stictaceae and two species of Parmelia suggest a defensive role against small, nonvisually-oriented invertebrate herbivores. ${ }^{11}$

In vascular plants, several studies have shown that sesqui- and diterpenoids may act as defense restricting herbivory. ${ }^{38}$ The nutrient rich species of Pseudocyphellaria, Sticta and Nephroma show a surprising lack of herbivory indicating that terpenes may play an important role in protecting these species with high nitrogen content. ${ }^{11}$

Fumarprotocetraric acid is a bitter depside occurring in many lichens which appear to deter herbivory. For example, neither Caldonia arbuscula nor $C$. rangiferina (both contain fumarprotocetraric acid) are eaten by reindeer, while they are attracted to $C$. alpestris which has no fumarprotocetraric acid. ${ }^{39}$ Concentrations of fumarprotocetraric acid vary greatly between younger and older thallus parts in Cladonia, with the greatest concentration occurring in metabolically active growing tips. ${ }^{40}$ Species containing depsides and depsidones such as diffractic acid, physodic and physodalic acids and salazinic acid which are bitter are avoided by Caribou in Canada. ${ }^{41}$

Parietin, an anthraquinone lichen substance appears to have a defensive role against herbivores. ${ }^{42}$ Lichen species of Teloschistaceae contain relative high contents of parietin. ${ }^{43}$

(+)-Usnic acid isolated from an Usnea sp. in the Ambewela area ${ }^{44}$ showed significant antitermite activity ( $80 \%$ mortality at $10 \mathrm{mg}$ ) against Glyptotermes dilatatus, which is a major live-wood tea-termite at low elevations. Although usnic acid is a well-known antimicrobial compound ${ }^{16}$ there is only one report of the insecticidal activity of usnic acid against the polyphagous herbivorous insect Spodoptera littoralis. ${ }^{16}$ Currently, the control methods of $G$. dilatatus are focused on the development of resistant clones and there are no reported chemicals which can be used in controlling the 
pest, and as such search for such compounds are important. ${ }^{45}$

\section{(e) Allergenic activity}

Contact dermatitis among forestry and horticultural workers has been attributed to the exposure to lichen substances. Among the many lichen substances responsible for such allergenic action are usnic acid, evernic acid, fumarprotocetraric acid, stictic acid and atranorin. Atranorin and stictic acid are capable of photosensitizing human skin as well as being contact allergens. ${ }^{46}$ Atranorin and other $\beta$-orcinol type depsides absorb UV radiation and this may account for their photo toxicity.

\section{Chemical ecology of lichens}

Sequestering of plant chemicals by insects is a well-known phenomenon. Specifically, butterflies of the family Lycaenidae are known to sequester plant chemicals. ${ }^{47}$ Larvae of Monarch butterflies (Nymphalidae) accumulate toxic cardiac glycosides in millk weeds, which are used by the adults to deter predators. ${ }^{48}$ Although the sequestration of lichen compounds by the moths of the families Arctiidae and Lithosiinae are known, butterflies are not known to sequester lichen compounds.
Many species of invertebrates live on and among lichens, using them for concealment, shelter or food. Over half of the orders of insects have associations with lichens. ${ }^{49}$

Moths belonging to the family Lepidoptera have the richest association with lichens. ${ }^{51}$ There are many examples of moth names reflecting the resemblance to lichens, such as the "pale lichen moth" (Crambidia pallida) and the "powdered lichen moth" (Bruceia pulverina). A noctuid moth, Zanclognatha theralis, in Tennessee, USA, was discovered to both feed on Usnea stigosa and look remarkably like the lichen. ${ }^{52}$

The experiments with polyphagous larvae of the moth Spodoptera littoralis (Noctuidae) demonstrated pronounced acute toxicity and feeding deterrency for frequently occurring lichen compounds such as (+)- and (-)-usnic acids and vulpinic acid at concentrations comparable to or even below those found in many lichens. ${ }^{58}$

Hesbacher et al. ${ }^{54}$ have shown that the lichen phenolics such as parietin, atranorin as well as the hydrolytic cleavage product of atranorin (methyl-2, 4-dihydroxy-3, 6-dimethylbenzoate) among other lichen compounds were detected in 11 different moth species of the family Arctiidae.<smiles>COC1=CC2C(=O)c3cc(C)cc(O)c3C(=O)C2C(O)=C1</smiles>

Parietin<smiles>CC(=O)c1c(C)cc(O)c(C)c1O</smiles>

Methyl-2, 4-dihydroxy-3, 6-dimethylbenzoate<smiles>CC(=O)c1c(C)cc(OC(=O)c2c(C)cc(O)c(C=O)c2O)c(C)c1O</smiles>

Atranorin 
<smiles>CCCCCCCCCCCCCCCCC(C)(C)C</smiles>

$\alpha$-collatolic acid<smiles>CC(=O)C1=C(O)C=C2Oc3c(C(C)=O)c(O)c(C)c(O)c3C2(C)C1=O</smiles>

(-)-Usnic acid<smiles>CC(=O)C(=C1OC(=O)C(c2ccccc2)=C1O)c1ccccc1</smiles>

Vulpinic acid

The moth larvae of Lithosiinae feed on epiphytic algae of trees or on the algal component of lichens. ${ }^{48}$ A recent survey for the presence of sequestered lichen compounds in several Lithosiinae species in Australia and Germany, demonstrated that the presence of lichen compounds is variable but wide spread in wildcaught imagines. ${ }^{48}$

Many snails and slugs (class: Gastropoda) feed on lichens. In Israel, two species of snails that eat lichens growing under the surface of lime stone rocks were discovered to be converting rock to soil at an amazing rate. The snails pass significant amounts of rock through their digestive tracts in the process of consuming the lichen. In addition, the snails were taking the nitrogen from the lichen and leaving it behind in the new soil. ${ }^{55}$ On the other hand, many lichen species contain bitter compounds that may discourage feeding by invertebrates. ${ }^{56}$ Although the ecological role of the sequestered compounds for the herbivores remains unknown, it is thought that they may be utilized for chemical defense against predators or pathogens. ${ }^{57}$

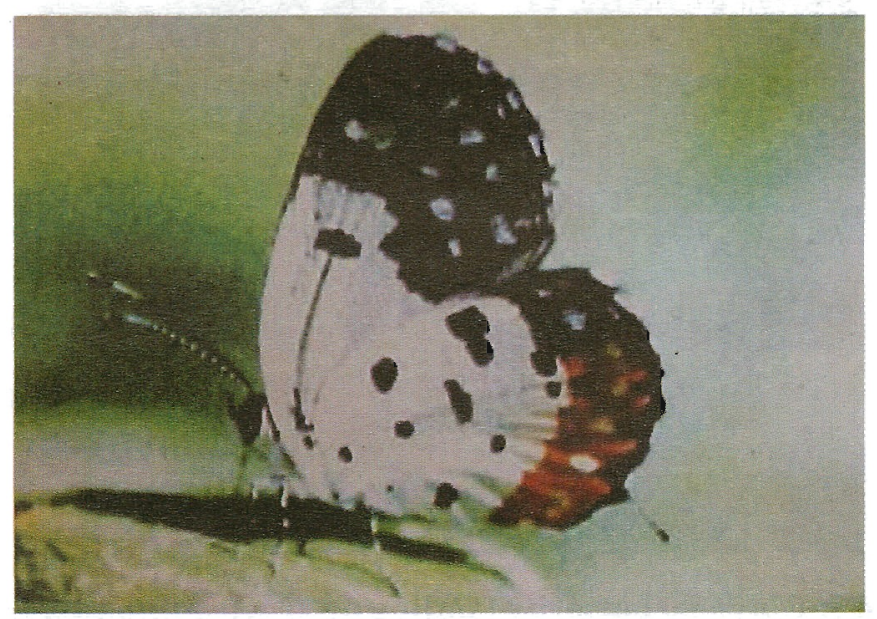

Figure 7: T. nyseus butterfly landing on B. calycinum 
Three species of lichen-grazing snails, Balea perversa, Chondrina clienta and Helicigona lapicida were found to sequester lichen compounds when feeding on the crustous lichen species Aspicilia calcarea, Caloplaca atra and Xanthoria parietina. The lichen compounds such as (+)-usnic acid or a-collatolic acid were detected in the feces of these snails, suggesting selective uptake of lichen compounds by the snails. ${ }^{57}$

Lycaenidae is the largest family of butterflies in Sri Lanka and consist of 40 genera, comprising 81 species. ${ }^{50}$ Some species of Lycaenidae live on plants, a few live on scaleinsects, others feed on the larvae and pupae of the large red ant Oecophylla smaragdina, while many are actually tended by ants in their nests. Some are cannibalistic, devouring larvae or the pupae of their own kind. ${ }^{50}$ Fruit-eating forms are also found in the Lycaenidae.

Talicada nyseus Guerin (red Pierrot) which belongs to the family Lycaenidae is distributed from Sri Lanka to Indo-China. The Sri Lankan population belongs to the nominotypical race, which flies through out the island below 4000 feet. The butterflies love human settlement being equally abundant in domestic gardens as it is in the wild. ${ }^{47}$ It is plentiful all over the island all the year round and flies slowly near the ground and settles frequently. ${ }^{50}$ The natural food source of its larvae is Bryophyllum calycinum (Sinhala: akkapana; Tamil: malai-kalli) (Figure 7).
During our studies of Sri Lankan lichens, we discovered the sequestration of lichen products belonging to the crustaceous lichen Leproloma sipmanianum Kummerl \& Leukert by the butterfly $T$. nyseus Guerin (red pierrot) (Lycaenidae) in Beragala ( $80^{\circ} 54^{\prime} 30^{\prime \prime} \mathrm{E}, 6^{\circ} 45^{\prime} 30^{\prime \prime}$ N), Uva province, Sri Lanka. ${ }^{58} T$. nyseus was found flying close to the extensive lichen thallus, growing on road side proterozoic rocks of gneiss and quartz schist which are exposed at road edges, and roosting on it periodically (Figure 8).

Pupae of the butterflies were also located anchored to the thallus surface. T. nyseus were collected from Beragala between the period from September 1996 and March 2001.

Out of seven butterfly collections made, on three occasions, five compounds namely, zeorin 1, $\beta$-sitosterol 2, a long-chain fatty acid ester 3, atranorin 4 , and $(+)$-usnic acid 5 , were present in wild-caught imagines (Figure 9). The butterflies which emerged from the pupae also contained these compounds.

The presence of these compounds in the butterfly was confirmed by comparative TLC studies and GC-MS with authentic lichen substances isolated from the lichen $L$. sipmanianum.

The butterflies found at the University of Peradeniya and Kandy contained only $\beta$-sitosterol

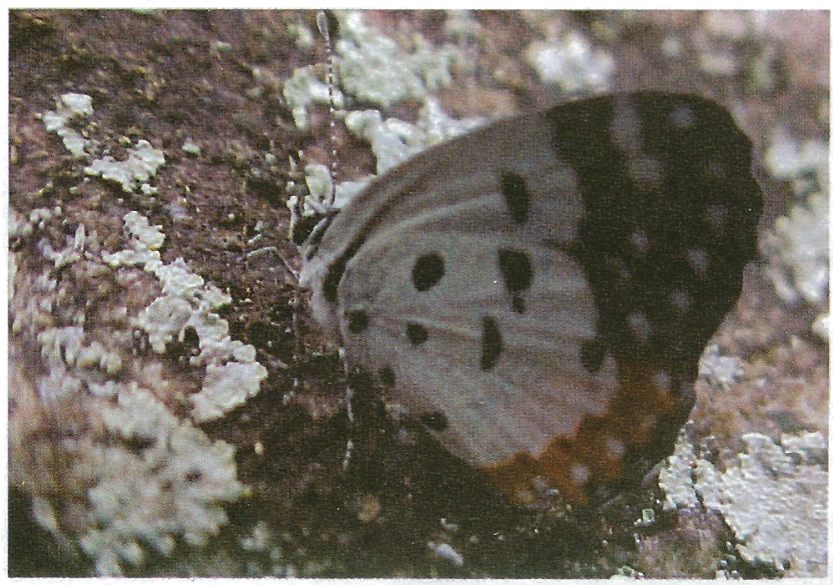

Figure 8: T. nyseus butterfly landing on $L$. sipmanianum lichen 


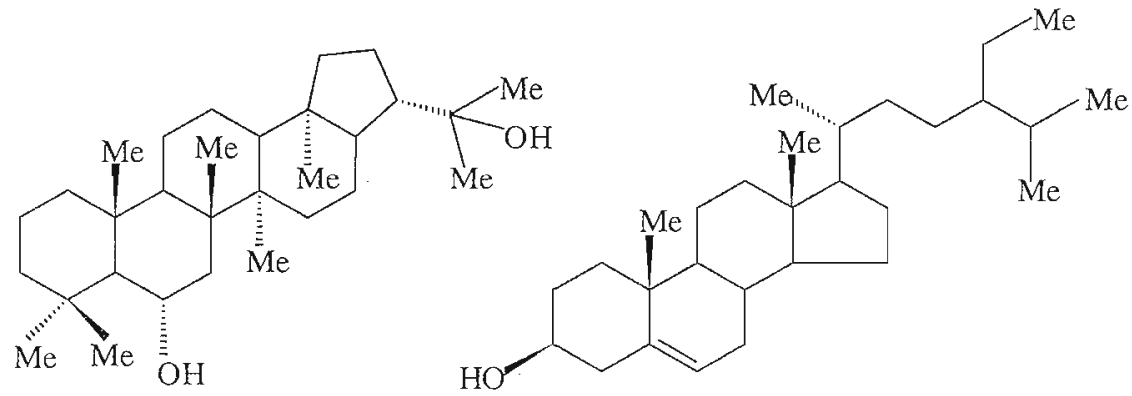

1

2

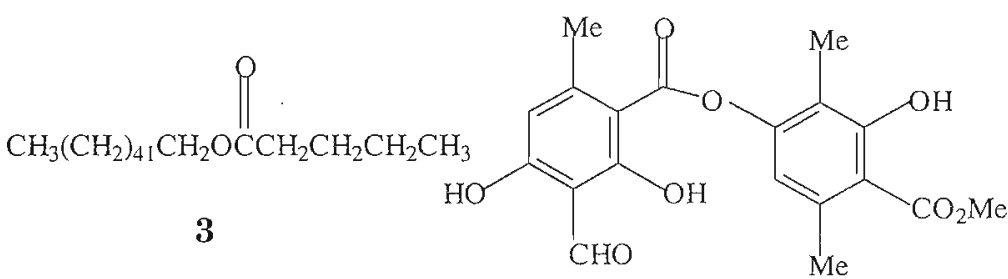

4<smiles>[M]C12C(=O)C(C(C)=O)C(O)C=C1Oc1c(C(C)=O)c(O)c(C)c(O)c12</smiles>

5

Figure 9: Structures of lichen compounds present in L. sipmanianum and T. nyseus: 1. Zeorin, 2. $\beta$ Sitosterol, 3. Fatty acid ester, 4. Atranorin, 5. (+)-Usnic acid.

2 (common plant sterol also found in the host plant $B$. calycinum) with no trace of other lichen compounds. It was concluded that the presence of lichen products of $L$. sipmanianum in adult $T$. nyseus butterflies indicated that its larvae may feed on the lichen although the natural food source is $B$. calycinum.

Out of the seven butterfly collections made from Beragala, all five compounds, (1) - (5) were present in adult butterflies on three occasions. Importantly, on two occasions, the butterflies which emerged from laboratory-reared pupae also contained compounds (1) - (5). (+)-Usnic acid (5) was present only on three occasions and atranorin (4) four times. T. nyseus collected during all the field visits contained zeorin (1), $\beta$-sitosterol (2) and the fatty acid ester (3).

In order to expand the scope of the study and investigate the presence of lichen products in $T$. nyseus in other areas of the island, butterflies were collected from four other locations: foot hills of Adam's peak in Central Province (80 $30^{\circ} 50^{\prime \prime} \mathrm{E}$, $\left.6^{\circ} 50^{\prime} \mathrm{N}\right)$, Peradeniya University premises $\left(80^{\circ} 35^{\prime}\right.$ $30^{\prime \prime} \mathrm{E}, 7^{\circ} 15^{\prime} \mathrm{N}$ ), from a domestic garden in Aniewatta, Kandy ( $\left.80^{\circ} 38^{\prime} \mathrm{E}, 7^{\circ} 17^{\prime} 30^{\prime \prime} \mathrm{N}\right)$, both in the Central Province and in Ukgalkalthota $\left(80^{\circ}\right.$ $52^{\prime} 30^{\prime \prime} \mathrm{E}, 6^{\circ} 39^{\prime} 30^{\prime} \mathrm{N}$ ) in the Uva Province. Butterflies were subjected to the same analysis protocol as described above using both TLC and GC-MS. Interestingly, the butterflies found at the University of Peradeniya and Kandy contained only $\beta$-sitosterol with no trace of other compounds. However, those collected in Ukgalkalthota contained atranorin (4) and $\beta$-sitosterol while butterflies at the foot-hills of Adam's peak contained ( + )-usnic acid (5) along with $\beta$ sitosterol. Examination of the extracts (hexane, dichloromethane and methanol) of air-dried plant material (140 g) of Bryophyllum calycinum by TLC and MPLC did not reveal the presence of lichen compounds (1), (3), (4) and (5). However, the dichloromethane extract $(1.50 \mathrm{~g})$ whose TLC showed the presence of $\beta$-sitosterol upon MPLC on silica gel (eluent: step gradient from dichloromethane: hexane (2: 3) to methanol: dichloromethane (1: 79)) yielded $\beta$-sitosterol as a colourless crystalline solid $(0.021 \mathrm{~g})$ confirming that $B$. calycinum contains $\beta$-sitosterol 2 and it could be the source of the butterfly.

It may be concluded that the presence of lichen products found in $L$. sipmanianum in adult 
T. nyseus butterfly indicates that its larvae can feed on the lichen although its natural food source is $B$. calycinum. In the case of $T$. nyseus individuals contained only $\beta$-sitosterol (Peradeniya and Kandy), the larvae probably used the natural food source as their only diet. On the other hand, the presence of atranorin (4) and (+)usnic acid (5), compounds which are found only in lichens, in the butterflies in Ukgalkalthota and at the foot-hills of Adam's peak, respectively, lends credence to the evidence accumulated in Beragala that the larvae of.T. nyseus may indeed sequester lichen products.

\section{References}

1. Huneck S.\& Yoshimura I. (1996). Identification of Lichen Substances, Springer, Berlin Heidelberg, New York.

2. Elix J. A. (1996). Biochemistry and secondary metabolites. In: Lichen Biology (Ed. Nash T. III), pp. 154-180. Cambridge University Press.

3. Culberson C. F. (1969). Chemical and Botanical Guide to Lichen Products. Univ. North Carolina Press, Chapel Hill.

4. Culberson C. F. \& Culberson W. L. (1976). Chemosyndromic variation in lichens. Systematic Botany 1: 325-339.

5. Culberson C. F. (1986). Biogenetic relationships of the lichen substances in the framework of systematics. Bryologist 89: 123-131.

6. Culberson C. F. (1972b). Improved conditions and new data for the identification of lichen products by a standardized thin-layer chromatographic method. Journal of Chromatography 72: 113-125.

7. Culberson C.F. \& Ahmadjian K. (1979). Standardmethode zur Dunnschicht chromatographi von Flechten substanzen. Herzogia 5: 1-24.

8. Culberson C. F., Culberson W. L. \& Johnson A. (1981). A Standardized TLC analysis of b-orcinol depsidones. Bryologist 84: 16-29.

9. Santesson J. (1969b). Chemical studies on lichens. 10 Mass spectrometry of lichens. Ark Kemi 30: 363-377.
10. Aproot A. (1987). Terpenoids in tropical Pyxinaceae (Lichenized fungi). XIV International Botanical Congress Abstracts, Berlin: 504 -507.

11. Rundel P. W. (1978). The ecological role of secondary lichen substances. Biochemical Systematics and Ecology 6: 157-170.

12. Wessels D. C. \& Schoemann P. (1988). Mechanisms and rate of whithering of Clarens sandstone by an endolithic lichen. South African Journal of Science 84: 274-277.

13. Brightman F. H. (1960). Antibiotics from lichens. Biology and Human Affairs 26: 1-5.

14. Smith A. L. (1920). Lichens. Cambridge University Press, London.

15. Heinrich G., Gries A., Muller H. \& Oswald K. (1989). Ruckblick. Drei Jahre nach Tschernobyl. Mitt Naturwiss Ver Steiermark 119: 5-13.

16. Ingolfsdottir K., Bloomfield S. F. \& Hylands P. J. (1985). In vitro evaluation of the antimicrobial activity of lichen metabolites as potential preservatives. Antimicroial Agents Chemother 28: 289-292.

17. Savicz V. P., Litvinov M. A. \& Moissejeva E. M. (1960). Ein Antibiotikum aus Flechten als Arzneimittel. Planta Medica 8: 192-202.

18. Irwin M. B. (1973). The Lichens. (Eds. Ahmadjian V. \& Hale M.), pp. 25. Academic Press, New York.

19. Takai M, Uehara, Y. \& Beisler J. A. (1979). Usnic acid derivatives as potential antineoplastic agents. Journal of Medicinal Chemistry 22: 1380-1384.

20. Hirayama T., Fujikawa F., Kasahara T., Otsuka M., Nishida N. \& Mizuno D. (1980). Anti-tumor activities of some lichen products and their degradation products. Yakugaku Zasshi 100: 755-759.

21. Shibamoto T. \& Wei C. I. (1984). Mutagenicity of lichen constituents. Environmental Mutagenesis 6: 757-762.

22. Hirabayashi K., Iwata S., Ito M., Shigeta S., Narui T., Mori T. \& Shibata S. (1989). Inhibitory effect of a lichen polysaccharide sulfate, GE-3- 
$S$, on the replication of human immunodeficiency virus (HIV) in vitro. Chemistry Pharmaceutical Bulletin 37: 2410-2344.

23. Demleitner S., Krams J. \& Franz G. (1991). Synthese and Antitumoraktivitat von Licheninderivaten. Pharmazie Unserer Zeit 20: 120.

24. Tokuzen R. (1971). Comparison of local cellular reaction to tumor grafts in mice treated with some plant polysaccharides. Cancer Research 31: 1590 .

25. Williams D. E., Bombuwela K., Lobkovsky E., De Silva E.D., Karunaratne V., Allen T., Clardy J. \& Andersen R. (1998). Ambewalamides A and B, Antineoplastic Epidithiapiperazinediones Isolated from the Lichen Usnea sp. Tetrahedron Letters 39: 9579-9582.

26. Karunaratne V., Bombuwela K. \& De Silva E. D. (1998). Ambewalamides A and B, Novel Antineoplastic Compounds from Sri Lankan Usnea sp. Proceedings of the Award Winning Papers, University of Peradeniya Research Sessions 3A, 83.

27. Neuss N., Nagarajan R., Molloy B. B. \& Huckstep L. L. (1968). Aranotin and related metabolites from Arachniotus aureus (Eidam) Schroeter. IV. Fermentation, isolation, structure elucidation, biosynthesis. Antimicrobial Agents Chemother 8: 213-219.

28. Kawahara N., Nozawa K., Yamazaki M., Nakajima S. \& Kawai K. (1990). Structures of novel epipolythiodioxopiperazines, emethallicins $\mathrm{B}, \mathrm{C}$, and $\mathrm{D}$, potent inhibitors of histamine release from Emericella heterothallica. Chemistry Pharmaceutical Bulletin (Tokyo) 38: 73-78.

29. Sugawara K., Sugawara F., Strobel G. A., Fu. Y., He C. H. \& Clardy J. (1985). Exserohilone, a novel phytotoxin produced by Exserohilium holmii. Journal of Organic Chemistry 50: 5631.

30. Hegde V. R., Patel M., Das P.R. \& Puar M.S. (1997). Novel thiodiketopiperazine fungal metabolites as epidermal growth factor receptor antagonists. Tetrahedron Letters 38: 911.

31. Pulliainen E. (1971). Nutritive value of some lichens used as food by reindeer in northeastern Lapland. Annales Zoologici Fennici 8: 385-389.
32. Peake J. F., \& James, P.W. (1967). Lichens and mollusca. Lichenologist 3: 425.

33. Gerson U. (1973). Lichen arthropod associations. Lichenologist 5: 434-443.

34. Sowter F.A. (1971). Mites (Acari) ans lichens. Lichenologist 5: 176.

35. Grandjean F. (1950). Observations ethologiques sur Camisiasegnis (Herm.) et Platynothris peltifer (Koch) (Acariens). Bulletin of the American Museum of Natural History 22: 224.

36. Saxena P. N. \& Saxena S. (1989). Insecticidal activity of some penta- and hexa-coordinated heterocyclic $\beta$-diketone derivatives of diorganotin (IV) against the stored product pest Rhizopertha (Coleoptera: Bostrichidae). Applied Organometallic Chemistry 8: 279-281.

37. Slansky F. (1979). Effect of the lichen chemicals atranorin and vulpinic acid upon feeding and growth of larvae of the yellow-stripped armyworm, Spodoptera ornithogalli. Enviornmental Entomology 8: 865-868.

38. Wright A. B. (1993). Peterson first guide to caterpillars of North America. Houghton Mifflin Co., Boston.

39. Lawrey J.D. (1980b). Correlations between lichen secondary chemistry and grazing activity by Palliferavaria. Bryologist 83(3): 328-334.

40. Laundon J. R. (1971a). Lichen communities destroyed by psocids. Lichenologist 5: 177.

41. Ahti T. (1977). Lichens in the boreal coniferous zone. In: Lichen ecology. (Eds. Seaward M. R. D.), pp. 145-181. Academic Press, London.

42. Yom-Tov Y. \& Galun M. (1971). Note of feeding habits of the desert snails Sphincterochila boissieri Charpentier and Trochoidea (Xerocrassa) seetzeni Charpentier. The Veliger 14: 86.

43. Maass W. S. G. (1975b). Lichen substances. V. Methylated derivatives of orsellenic acid, lecanoric acid, and gyrophoric acid from Pseudocyphellaria crocata. Canadian Journal of Botany 53: 1031-1039. 
44. KathirgamanatharS., Williams D. E., Andersen R. J., Bombuwela K., De Silva D. \& Karunaratne V. (2005). b-orcinol depsidones from the lichen Usnea sp. Natural Products Research 19 (7): 695701.

45. Sivapalan P., Kulasekeran S. \& Kathiravetpillai S. (1986). Hand Book on Tea, Tea Research Institute, Sri Lanka.

46. Benzera C., Ducombs G., Sell Y. \& Foussereau J. (1985). Plant Contact Dermatitis (Ed. Brian C. Decker), pp. 50-51. Toronto.

47. d'Abrera B. (1998). Butterflies of Ceylon. pp. 188. Welpac Printing \& Packaging Pvt. Ltd., Singapore.

48. Rawlins J. E. (1984). Mycophagy in Lepidoptera. In Fungus-Insect Relationships. (Eds. Wheeler Q. \& Blackwell M.), pp. 382-423. Columbia University Press, New York.

49. Richardson D. H. S. (1977). Lichens and vertebrates. In: Lichen Ecology. (Ed. Seaward M. R. D) pp. 121-144. Academic Press, London.

50. Woodhouse L. G. O. (1952). The butterfly fauna of Ceylon. (2 $2^{\text {nd }}$ Edition). pp. 57. Ceylon Govt. Press, Colombo.

51. Gerson U. (1950). Lichen Ecology. (Ed. Seaward M. R. D) Academic Press, London

52. Sigal L. L. (1984). Of lichens and lepidopterans. Bryologist 87 (1): 66-68.

53. Emmerich R., Giez I., Lange O. L. \& Proksch P. (1993). Toxicity and anti feedant activity of lichen compounds against the polyphagous herbivorous insect Spodoptera littoralis. Phytochemistry 33: 1389-1394.

54. Hesbacher S., Giez I., Embacher G., Fiedler K., Max W., Trawoger A., Turk R., Lange O. L. \& Proksch P. (1995). Sequestration of lichen compounds by lichen-feeding members of the Arctiidae (Lepidoptera). Journal of Chemical Ecology 21(12): 2079-2089.

55. Hesbacher S. B., Baur A. Bauer \& P. Proksch (1995). Sequestration of lichen compounds by three species of terrestrial snails. Journal of Chemical Ecology 21(2): 233-246.

56. Jones C. G. \& Shachak M. (1990). Fertilization of the desert soil by rock-eating snails. Nature 346: $839-841$.

57. Lawrey J. D. (1986). Biological role of lichen substances. Bryologist 89(2): 111-122.

58. Orange A., Wolseley P., Karunaratne V. \& Bombuwela K. (2001). Two Leprarioid Lichens New to Sri Lanka. Bibliotheca Lichenologica 78: 327-333.

59. Karunaratne V., Bombuwela K., Kathirgamanathar S., Kumar V., Karuaratne D. N. Ranawana K. B., Wijesundara D. S. A., Weerasooriya A. \& E. D. De. Silva. (2002). An association between the butterfly Talicada nyseus and the lichen Leproloma sipmanianum as evidenced from chemical studies. Current Science 83 (6): 742-745.

60. Bergwein I. K. (1972). Moss fragrance in modern perfumery. Dragoco Report 3: 43-48. 